\title{
Experimental behaviour of a steel structure under natural fire
}

\author{
F. Wald ${ }^{\mathrm{a}}$, L. Simões da Silva ${ }^{\mathrm{b}, *}$, D.B. Moore ${ }^{\mathrm{c}}$, T. Lennon ${ }^{\mathrm{d}}$, M. Chladnáe, \\ A. Santiago ${ }^{b}$, M. Beneš ${ }^{\mathrm{a}}$, L. Borges ${ }^{\mathrm{f}}$ \\ ${ }^{a}$ Department of Steel Structures, Czech Technical University in Prague, Czech Republic \\ ${ }^{\mathrm{b}}$ Department of Civil Engineering, University of Coimbra, ,Polo II, Pinhal de Marrocos, 3030-290 Coimbra, Portugal \\ ${ }^{\mathrm{c}} B C S A-B r i t i s h$ Constructional Steelwork Association, London, UK \\ ${ }^{\mathrm{d}}$ Building Research Establishment, Watford, UK \\ ${ }^{\mathrm{e}}$ Department of Steel Structures, Slovak Technical University, Slovak Republic \\ ${ }^{\mathrm{f}}$ Steel Structures Laboratory, École Polytechnique Fédérale de Lausanne, Switzerland
}

Received 1 August 2005; received in revised form 21 November 2005; accepted 8 May 2006

Available online 15 August 2006

\begin{abstract}
Current design codes for fire resistance of structures are based on isolated member tests subjected to standard fire conditions. Such tests do not reflect the behaviour of a complete building under either normal temperature or fire conditions. Many aspects of behaviour occur due to the interaction between members and cannot be predicted or observed in tests of isolated elements. Performance of real structures subject to real fires is often much better than that predicted from standard tests due to structural continuity and the provision of alternative load paths.

This paper reports on the results of a collaborative research project (Tensile membrane action and robustness of structural steel joints under natural fire, European Community FP5 project HPRI-CV 5535) involving the following institutions: Czech Technical University (Czech Republic), University of Coimbra (Portugal), Slovak Technical University (Slovak Republic) and Building Research Establishment (United Kingdom). It consists of an experimental programme to investigate the global structural behaviour of a compartment on the 8-storey steel-concrete composite frame building at the Cardington laboratory during a BRE large-scale fire test, aimed at the examination of the temperature development within the various structural elements, the corresponding (dynamic) distribution of internal forces and the behaviour of the composite slab, beams, columns and connections.
\end{abstract}

(C) 2006 Elsevier Ltd. All rights reserved.

Keywords: Structural engineering; Steel and composite structures; Full-scale tests; Fire design; Structural integrity

\section{Introduction}

Significant developments have been made in analysing the behaviour of steel-framed structures under fire conditions in the last 10 years. Due to the high cost of full-scale fire tests and size limitations of existing furnaces, these studies are based on the observation of real fires and on tests performed on isolated elements subjected to standard fire regimes, which serve as reference heating, but do not model the natural fire. However, the failure of the World Trade Centre on 11th September 2001 and, in particular, of building WTC7, alerted the engineering profession to the

\footnotetext{
*Corresponding author. Tel.: + 351239797216 ; fax: + 351239797217.

E-mail address: luisss@dec.uc.pt (L. Simões da Silva).
}

possibility of connection failure under fire conditions. Many aspects of behaviour occur due to the interaction between members and cannot be predicted or observed from isolated tests, such as global or local failure of the structure, stresses and deformations due to the restraint to thermal expansion by the adjacent structure, redistribution of internal forces, etc. Moreover, isolated tests do not reflect the behaviour of a complete structure.

Unlike the standard fire curve a natural fire is characterized by three phases: a growing phase, a full developed phase and a decay phase. It is necessary to evaluate not only the effect on the structural resistance during the heating phase, but also the high cooling strains in the joint induced by distortional deformation of the heated elements during the decay phase. 
Table 1

Summary of full-scale fire tests

\begin{tabular}{|c|c|c|}
\hline Authors & Year & Objectives \\
\hline Pettersson et al. [2] & 1976 & $\begin{array}{l}\text { Gas time-temperature in different fire compartments. Data in a form readily accessible to the } \\
\text { practising engineer. }\end{array}$ \\
\hline Witteveen et al. [3] & 1977 & $\begin{array}{l}\text { The first reported test to assess structural behaviour under fire conditions. The stability of braced and } \\
\text { unbraced frame at elevated temperature was studied. }\end{array}$ \\
\hline Kruppa [4] & 1981 & Behaviour of external steel columns in a fire compartment. \\
\hline Genes [5] & 1982 & $\begin{array}{l}\text { Large-scale fire test on a compartment designed to simulate two floors of a } 20 \text {-storey building, in } \\
\text { order to assess the performance of protected beams. }\end{array}$ \\
\hline Latham et al. [6] & 1985 & $\begin{array}{l}\text { Steel time-temperature curves for unprotected structural steelwork for several sections exposed in a } \\
\text { large fire compartment; variation of the fire load, the ventilation conditions and the thermal } \\
\text { properties of the enclosing surfaces. }\end{array}$ \\
\hline Rubert and Schaumann [7] & 1986 & $\begin{array}{l}\text { Tested a series of quarter-to-half scale fire tests on steel sub-assemblies under fire in order to obtain } \\
\text { the failure temperature of the heated steel members. }\end{array}$ \\
\hline Anon $[8]$ & 1986 & Fire behaviour of steel and composite construction. \\
\hline Cooke and Latham [9] & 1987 & $\begin{array}{l}\text { First test on a full-size loaded steel frame subjected to a natural fire using wooden cribs. This test } \\
\text { showed that the performance of the frame was better than that of the individual elements as a result of } \\
\text { the connection continuity that may be exploited to provide increased fire resistance of the beam. }\end{array}$ \\
\hline Thomas et al. [10] & 1992 & $\begin{array}{l}\text { Performance of light hazard sprinkler systems in real compartments. Structural behaviour of an } \\
\text { unprotected composite structure. }\end{array}$ \\
\hline Cardington Laboratory & $1993-2003$ & See $\S 2.3$ of this paper. \\
\hline
\end{tabular}

In order to address these issues, and to improve the knowledge of the structural integrity of structures under fire conditions, it is the objective of this paper to report on the results of a collaborative research project (Tensile membrane action and robustness of structural steel joints under natural fire, European Community FP5 project HPRI - CV 5535) involving the following institutions: Czech Technical University (Czech Republic), University of Coimbra (Portugal), Slovak Technical University (Slovak Republic) and Building Research Establishment (United Kingdom). It consists of an experimental programme to investigate the global structural behaviour of a compartment on the 8-storey steel-concrete composite frame building at Cardington Laboratory during a BRE large-scale fire test on January 16, 2003, aimed at the examination of the temperature development within the various structural elements, the corresponding (dynamic) distribution of internal forces and the behaviour of the composite slab, beams, columns and connections.

\section{Experimental research on the fire performance of structures}

\subsection{Full-scale fire tests}

Over the years many isolated member tests have been carried out in several institutions. However, investigations involving full-scale tests under natural fire are limited. The development of the Cardington Laboratory of the Building Research Establishment (BRE) has provided the opportunity to carry out several research projects that included full-scale fire tests. A complete state-of-art description of the experimental observations can be found in Wang [1], a brief summary being presented in Table 1 .

\subsection{The Cardington Laboratory}

The Cardington Laboratory is a unique worldwide facility for the advancement of the understanding of whole-building performance. Most aspects of a building's lifecycle, from fabrication to fire resistance and explosions through to demolition, can be investigated on real buildings. This facility is located at Cardington, Bedfordshire, UK and consists of a former airship hangar with dimensions $48 \mathrm{~m} \times 65 \mathrm{~m} \times 250 \mathrm{~m}$. It is used by industrial organizations, universities and research institutes, government departments and agencies. The BRE's Cardington Laboratory comprises three experimental buildings: a sixstorey timber structure, a seven-storey concrete structure and an eight-storey steel structure.

The steel test structure was built in 1993. It is a steel framed construction using composite concrete slabs supported by steel decking in composite action with the steel beams. It has eight storeys $(33 \mathrm{~m})$ and is five bays wide $(5 \times 9=45 \mathrm{~m})$ by three bays deep $(6+9+6=21 \mathrm{~m})$ in plan, see Fig. 1. The structure was built as non-sway with a central lift shaft and two end staircases providing the necessary resistance against lateral wind loads. The main steel frame was designed for gravity loads, the connections consisting of flexible end plates for beam-to-column connections and fin plates for beam-to-beam connections were designed to transmit vertical shear loads. The building 


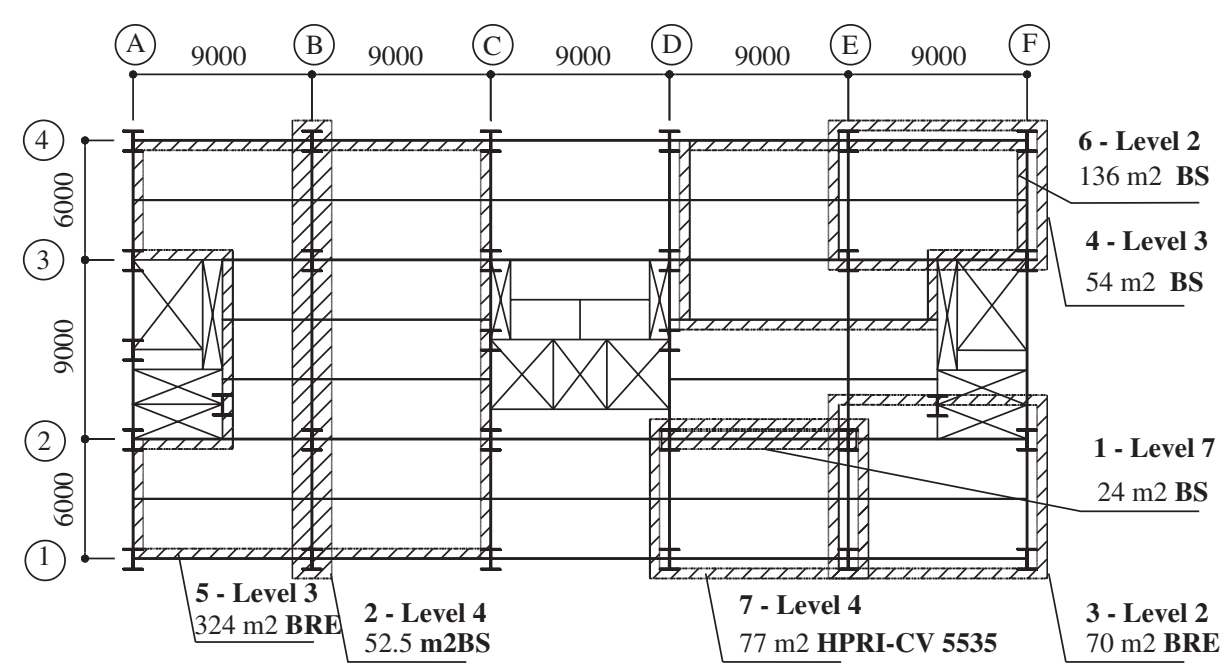

Fig. 1. The Cardington fire tests on steel structure.

Table 2

Fire test on steel structure in Cardington Laboratory [15]

\begin{tabular}{|c|c|c|c|c|c|}
\hline \multirow[t]{2}{*}{ No. } & \multirow[t]{2}{*}{ Test } & \multicolumn{2}{|c|}{ Fire compartment } & \multicolumn{2}{|l|}{ Load } \\
\hline & & Size, $(\mathrm{m})$ & Area $\left(\mathrm{m}^{2}\right)$ & Fire & Mechanical (\%) \\
\hline 1 & One beam heated by gas & $8 \times 3$ & 24 & Gas & 30 \\
\hline 2 & One frame heated by gas & $21 \times 2.5$ & 53 & Gas & 30 \\
\hline 3 & Corner compartment & $9 \times 6$ & 54 & $40 \mathrm{~kg} / \mathrm{m}^{2}$ of wood cribs & 30 \\
\hline 4 & Corner compartment & $10 \times 7$ & 70 & $45 \mathrm{~kg} / \mathrm{m}^{2}$ of wood cribs & 30 \\
\hline 5 & Large compartment & $21 \times 18$ & 342 & $40 \mathrm{~kg} / \mathrm{m}^{2}$ of wood cribs & 30 \\
\hline 6 & Office-Demonstration & $18 \times 9$ & 136 & $45 \mathrm{~kg} / \mathrm{m}^{2}$ of wood cribs & 30 \\
\hline 7 & Structural integrity & $11 \times 7$ & 77 & $40 \mathrm{~kg} / \mathrm{m}^{2}$ of wood cribs & 56 \\
\hline
\end{tabular}

simulates a real commercial office in the Bedford area and all the elements were verified according to British Standards and checked for compliance with the provisions of the Structural Eurocodes.

The building was designed for a dead load of $3.65 \mathrm{kN} / \mathrm{m}^{2}$ and an imposed load of $3.5 \mathrm{kN} / \mathrm{m}^{2}$, see [11]. The floor construction is of steel deck and light-weight in situ concrete composite floor, incorporating an anti-crack mesh of $142 \mathrm{~mm}^{2} / \mathrm{m}$ in both directions. The floor slab has an overall depth of $130 \mathrm{~mm}$ and the steel decking has a trough depth of $60 \mathrm{~mm}$.

\subsection{Fire tests at Cardington Laboratory}

Seven large-scale fire tests at various positions within the experimental building were conducted; see Fig. 1 and Table 2 [12]. The main objective of the compartment fire tests was to assess the behaviour of structural elements with real restraint under a natural fire.

The first test performed in Cardington was a restrained beam test involving a single $305 \times 165 \times 40 \mathrm{UB}$ composite beam section supporting the seventh floor of the building [13]. A gas-fired furnace was used to heat the beam to approximately $900{ }^{\circ} \mathrm{C}$. The second test, a plane frame test, involved heating a series of beams and columns across the full width of the building. Again, a gas-fired furnace was used to heat the steelwork to approximately $800^{\circ} \mathrm{C}$. The third test, the British Steel corner compartment test was the first natural fire carried out in the Cardington Laboratory, representing a typical office fire (timber cribs were used to provide a fire load of $45 \mathrm{~kg} / \mathrm{m}^{2}$ ). In this test, both the perimeter beams and the columns were fire protected with the internal beam unprotected. Load bearing concrete blocks were used for the compartment walls. The fourth test, the BRE corner compartment test also used timber cribs to provide a fire load of $40 \mathrm{~kg} / \mathrm{m}^{2}$. The compartment walls were constructed using fire-resistant board and the northern boundary was formed by constructing doubleglazed aluminium screens. All columns were protected up to and including the connections. It was observed that the fire development was largely influenced by the lack of oxygen in the compartment [14]. The fifth test was the largest compartment test in the world. The compartment was designed to represent a modern open-plan office $(18 \mathrm{~m} \times 21 \mathrm{~m})$. The compartment was bounded by fireresistant walls. The main aim of this test was to investigate the ability of a large area of composite slab to support the applied load once the main beams had failed. 
Table 3

Summary of results from major fire tests in the Cardington laboratory [16]

\begin{tabular}{|c|c|c|c|c|c|c|c|}
\hline No. & Org. & Floor & Time (min) to max. atmosphere temp. & \multicolumn{2}{|c|}{ Maximum temperature $\left({ }^{\circ} \mathrm{C}\right)$} & \multicolumn{2}{|c|}{ Measured deformations (mm) } \\
\hline 1 & $\mathrm{BS}^{\mathrm{a}}$ & 7 & 170 & 913 & 875 & 232 & 113 \\
\hline 2 & BS & 4 & 125 & 820 & 800 & 445 & 265 \\
\hline 3 & BS & 3 & 114 & 1000 & 903 & 269 & 160 \\
\hline 4 & $\mathrm{BRE}^{\mathrm{b}}$ & 2 & 75 & 1020 & 950 & 325 & 425 \\
\hline 5 & BRE & 3 & 70 & - & 691 & 557 & 481 \\
\hline
\end{tabular}

${ }^{\mathrm{a}} \mathrm{BS}$, British Steel (now Corus).

${ }^{\mathrm{b}}$ BRE, Building Research Establishment.

${ }^{\mathrm{c}} \mathrm{C}$ VUT, collaborative research proposed by Czech Technical University.
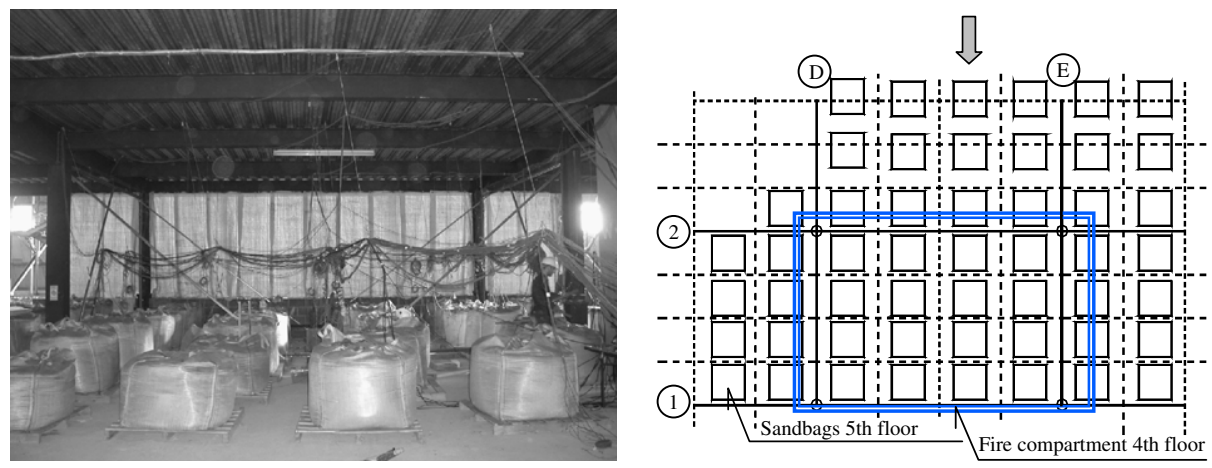

Fig. 2. Sandbags on the 5 th floor.

Consequently, all the beams had no fire protection and all columns were fire protected. Again, the ventilation conditions governed the fire severity. In the demonstration test (sixth test), unlike in the previous tests, real furniture (desks, chairs, filling cabinets, computer terminals, etc.) were used to provide the fire load. The ventilation was provided by windows and blank openings. The beams were unprotected while the columns were protected. This test was characterized by a rapid rise in temperature representing a severe fire scenario. The principal results of these tests are summarized in Table 3 [16], where, for ease of comparison, the 7 th test was also included.

\section{Structural integrity test program}

\subsection{Fire compartment}

The fire test was carried out in a centrally located compartment of the building (Fig. 1), enclosing a plan area of $11 \mathrm{~m} \times 7 \mathrm{~m}$ on the 4 th floor [16], after 4 months of preparation. The identification of the compartment is illustrated in Fig. 2.

The mechanical load was simulated using sandbags, each weighing $1100 \mathrm{~kg}$. Fig. 2 illustrates the loaded area on the 5th floor. In addition to the self-weight of the structure, sandbags were used to represent the following mechanical loadings: the remaining permanent actions, $100 \%$ of variable permanent actions and $56 \%$ of live actions. The mechanical load was designed to reach the local collapse of the floor at the peak temperature, based on analytical and FE simulations [17].

The fire load was provided by $40 \mathrm{~kg} / \mathrm{m}^{2}$ of wooden cribs (moisture contents $<14 \%$ ) covering the compartment floor area (Fig. 3). The fire compartment was bounded with three layers of plasterboard $(15 \mathrm{~mm}+12.5 \mathrm{~mm}+15 \mathrm{~mm})$ with a thermal conductivity around $0.19-0.24 \mathrm{~W} / \mathrm{mK}$. In the external wall (gridline 1) the plasterboard was fixed to a $1.5 \mathrm{~m}$ high brick wall. An opening $1.27 \mathrm{~m}$ high and $9 \mathrm{~m}$ long simulated an open window to ventilate the compartment and to allow the observation of the behaviour of the various elements. Preliminary calculations of the complex simulation of fire development predicted a short and hot fire [16].

The columns, external joints and connected beam $(1.0 \mathrm{~m}$ from the joints only) were fire protected to prevent global structural instability (Fig. 4). The material protection used was $15 \mathrm{~mm}$ of Cafco300 vermiculite-cement spray, with a thermal conductivity of $0.078 \mathrm{~W} / \mathrm{mK}$ at room temperature.

\subsection{Structural arrangement}

The steel structure exposed to fire consists of two beam sections $(356 \times 171 \times 51 \mathrm{UB}$ for the edge beams and the $6 \mathrm{~m}$ 

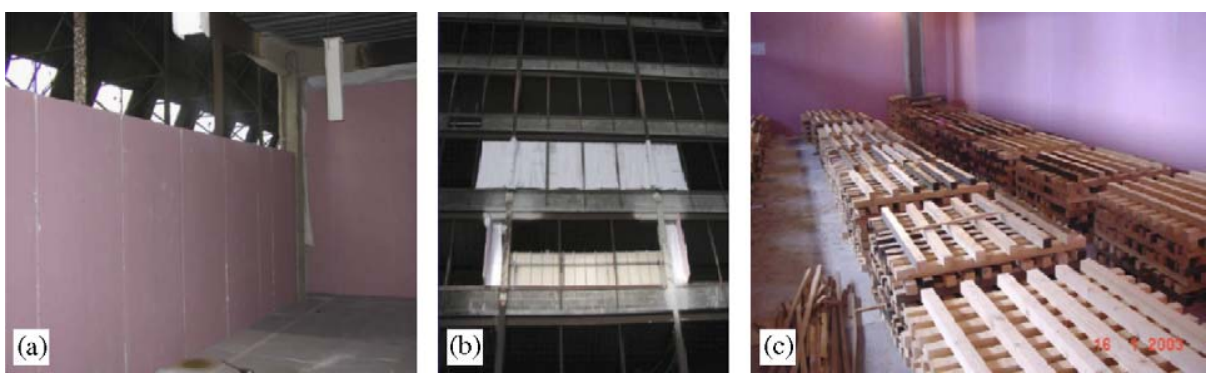

Fig. 3. (a) internal view of the compartment; (b) external view of the compartment and (c) fire loading.

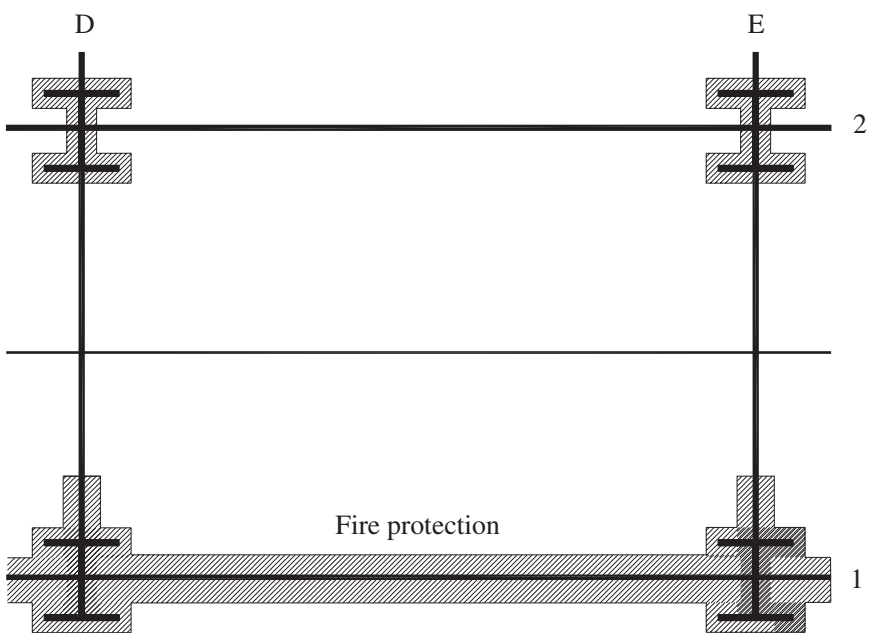

Fig. 4. Fire protection arrangement.

primary beams and $305 \times 165 \times 40 \mathrm{UB}$ for the internal secondary beams $)$ and two columns $(305 \times 305 \times 198 \mathrm{UC}$ and $305 \times 305 \times 137 \mathrm{UC}$ ) as shown in Fig. 5. The joints were a cruciform arrangement of a single column with either three or four beams connected, respectively, to the column flange or web. The composite behaviour was achieved by a concrete slab over the beams cast on shear studs. The measured sections geometry is presented in Fig. 6 and Table 4.

\subsection{Laboratory equipment and instrumentation}

The main requirements of the instrumentation were to measure the temperature, the distribution of internal forces and the deflected shape of the floor and of the main structural elements. The instrumentation included thermocouples, strain gauges and displacement transducers. A total of 133 thermocouples were used to monitor the temperature in the connections and beams within the compartment, the temperature distribution through the slab and the atmosphere temperature within the compartment. An additional 14 additional thermocouples were used to monitor the temperature of the protected columns. In order to measure the elements stresses and deformations, two different types of gauge were used: high temperature ones and ambient temperature ones. In the exposed and un-protected elements high-temperature strain

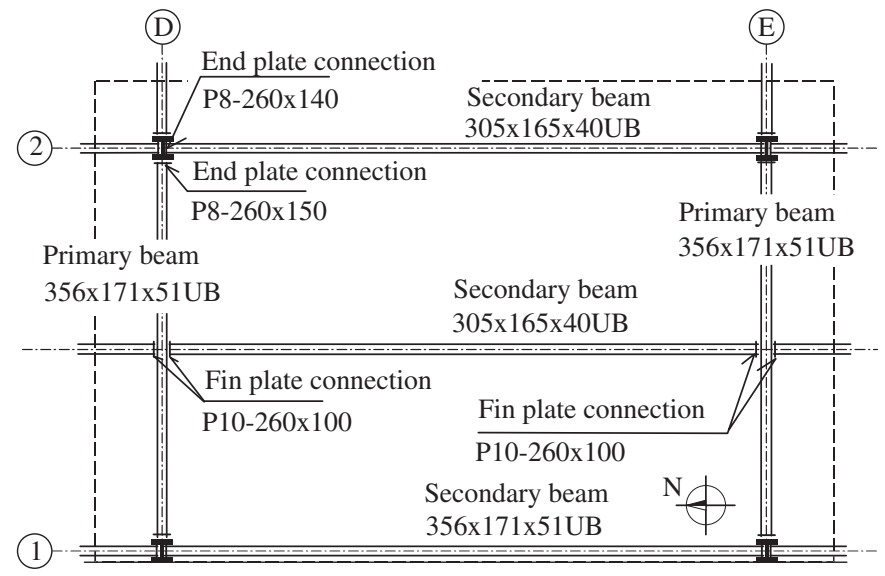

Fig. 5. Arrangement of members in selected fire compartment.

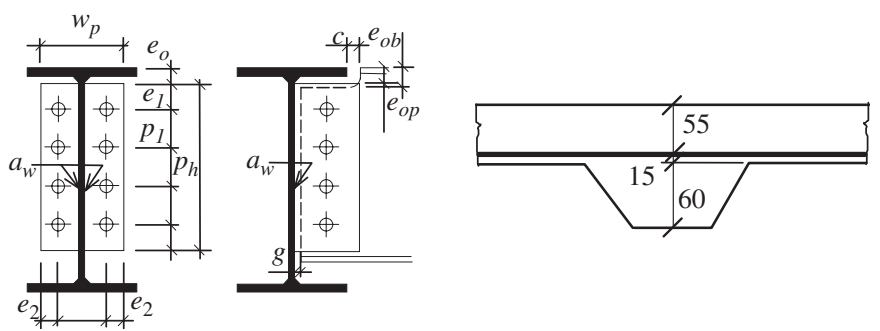

Fig. 6. Connection and slab geometry.

gauges were used. The number of these instruments (9) was limited because of economic reasons, so these strain gauges were used in the connections (fin plate and end plateminor axis) only (Fig. 7). In the protected columns and unexposed elements a total of 47 ambient strain gauges were installed. Twenty five vertical displacement transducers were installed directly above the 5th floor, in a square mesh, to measure the deformation of the concrete slab, see Fig. 8. Twelve additional transducers were used to measure the horizontal movement of the columns and the Laboratory 10 video cameras and two thermo imaging cameras recorded the fire and smoke development, the structural deformations and the temperature distribution with time. 
Table 4

Connections measured geometry

\begin{tabular}{|c|c|c|c|c|c|c|c|c|c|c|c|c|}
\hline$\frac{\text { Connection }}{\text { Fin plate }}$ & $\begin{array}{l}\text { Grid number } \\
\text { D1.5 }\end{array}$ & $\frac{h_{\mathrm{p}}(\mathrm{mm})}{259}$ & $\frac{w_{\mathrm{p}}(\mathrm{mm})}{100}$ & $\frac{t_{\mathrm{p}}(\mathrm{mm})}{10}$ & \multicolumn{2}{|c|}{$e_{0}(\mathrm{~mm})$} & $\frac{e_{1}(\mathrm{~mm})}{40}$ & $\frac{p_{1}(\mathrm{~mm})}{60}$ & $\frac{e_{2}(\mathrm{~mm})}{50}$ & $\frac{g(\mathrm{~mm})}{10}$ & $\begin{array}{l}c(\mathrm{~mm}) \\
20\end{array}$ & $\frac{a_{\mathrm{w}}(\mathrm{mm})}{6}$ \\
\hline & E1.5 & 260 & 100 & 10 & 25 & 25 & 40 & 60 & 50 & 9 & 20 & 7 \\
\hline & $\mathrm{D} 2 \mathrm{~min}$ & 262 & 140 & 8 & 25 & & 40 & 60 & 30 & - & - & 6 \\
\hline & E2 maj & 259 & 150 & 8 & 22 & & 40 & 60 & 30 & - & - & 6 \\
\hline & $\mathrm{E} 2 \mathrm{~min}$ & 259 & 140 & 8 & 25 & & 40 & 60 & 30 & - & - & 6 \\
\hline
\end{tabular}

Bolts

M20

Being: $h_{\mathrm{p}}$ the height of the plate, $w_{\mathrm{p}}$ the width of the plate, $t_{\mathrm{p}}$ the thickness of the plate, $e_{0}$ distance between the upper flange and the plate., $e_{1}$ the end distance from the centre of the fastener hole to the adjacent end of any part, measured in the direction of the load transfer, $p_{1}$ the spacing between centres of fasteners in a line in the direction of load transfer, $\mathrm{e}_{2}$ the edge distance from the centre of the fastener hole to the adjacent edge of any part, measured at right angles to the direction of the load transfer, $g$ gap between the web of the primary beam and secondary beam, c distance between the upper flange of primary beam and secondary beam, $a_{\mathrm{w}}$ the thickness of the weld on the beam web.

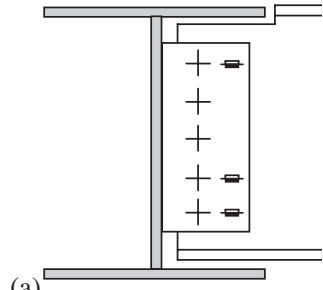

(a)

High temperature strain gauges

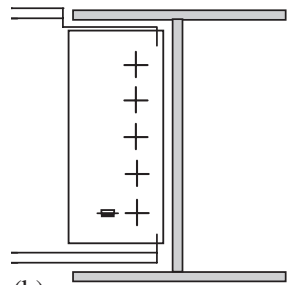

(b)

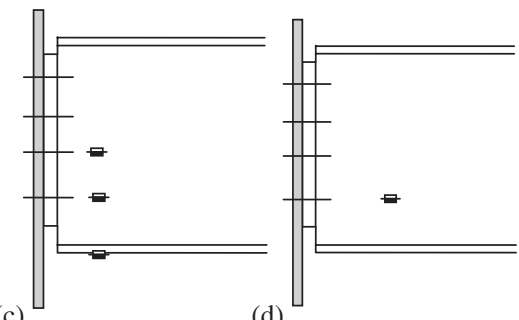

(d)

Fig. 7. Location of the high-temperature strain gauges: (a) D1.5; (b) E1.5; (c) D2; (d) E2.

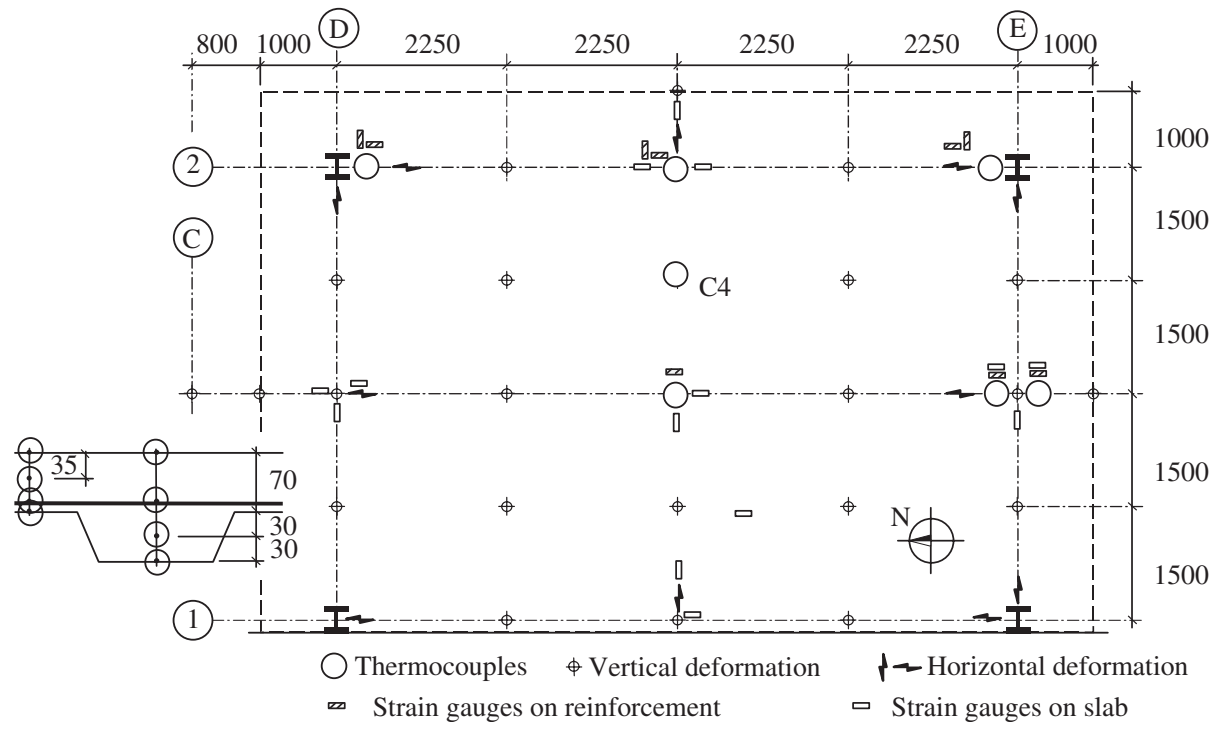

Fig. 8. Location of measurements on the slab, at 5th floor level.

\subsection{Mechanical properties of structure}

Table 5 reproduces the material properties at ambient temperature for the steel and concrete [11]. The actual concrete strength was assessed during the experimental preparation of the integrity test using non-destructive testing [16], while the measured steel properties were obtained during building construction. 
Table 5

Material properties of tested elements, [11] and [16]

\begin{tabular}{|c|c|c|c|c|c|c|c|c|}
\hline \multirow[t]{2}{*}{ Material } & \multicolumn{2}{|c|}{ Ultimate Stress (MPa) } & \multicolumn{2}{|c|}{ Yield Stress (MPa) } & \multicolumn{2}{|c|}{ Compressive Strength (MPa) } & \multicolumn{2}{|c|}{ Tensile Strength $(\mathrm{MPa})$} \\
\hline & Nominal & Measur & Nominal & Measur & Nominal $f_{\mathrm{c}, \mathrm{k}}$ & Measur $f_{\text {ck, cube }}$ & Nominal & Measur \\
\hline \multicolumn{9}{|l|}{ Steel } \\
\hline S275 & 430 & 469 & 275 & 303 & - & - & - & - \\
\hline S355 & 510 & 544 & 355 & 396 & - & - & - & - \\
\hline \multicolumn{9}{|l|}{ Plate } \\
\hline Grade 43 & 430 & - & 275 & - & - & - & - & - \\
\hline \multicolumn{9}{|l|}{ Bolts } \\
\hline 8.8 & 800 & 869 & 640 & - & - & - & - & - \\
\hline \multicolumn{9}{|l|}{ Concrete } \\
\hline LW $35 / 40$ & - & - & - & - & 35 & $\begin{array}{l}39,39 \\
\pm 0,48\end{array}$ & 3.2 & - \\
\hline \multicolumn{9}{|l|}{ Reinforc. } \\
\hline A142 mesh: T6@200mm & - & - & - & - & - & - & - & - \\
\hline
\end{tabular}
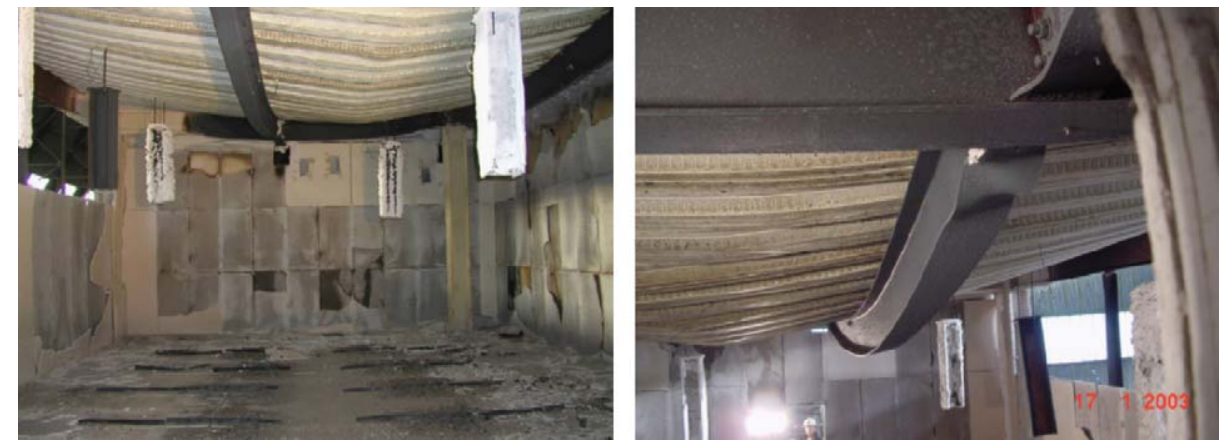

Fig. 9. Compartment after fire, residual deformation $925 \mathrm{~mm}$, no local collapse of structure.

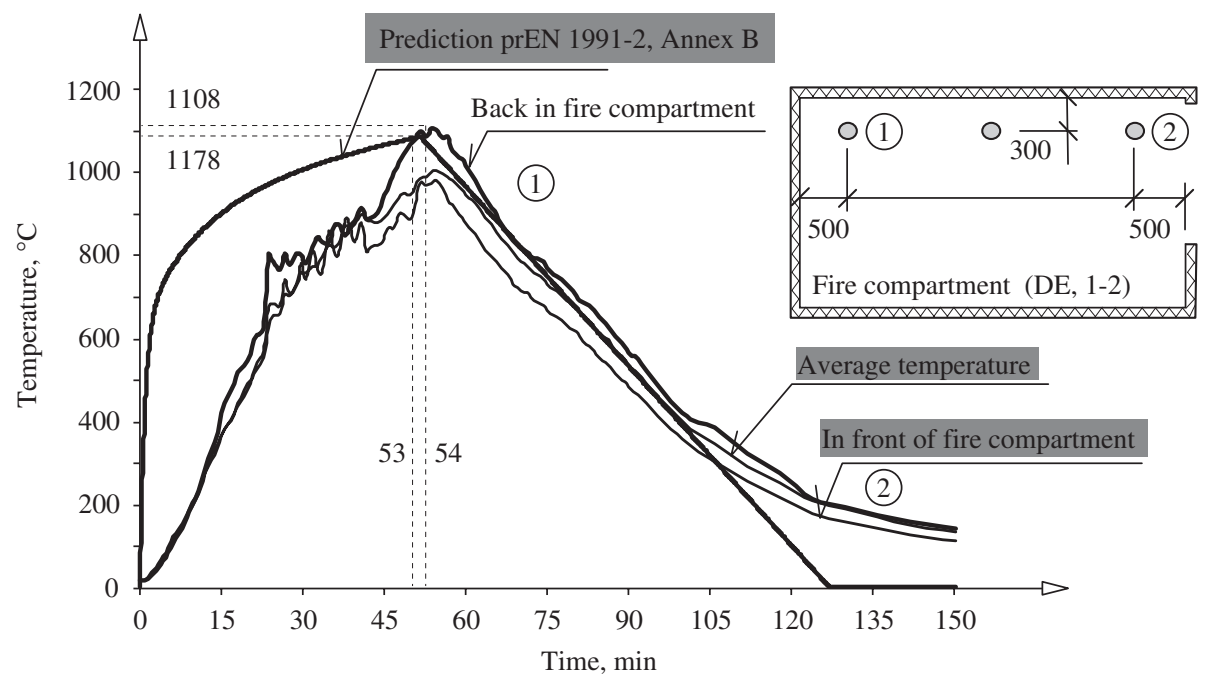

Fig. 10. Compartment temperature.

\section{Experimental observations}

\subsection{Fire development and compartment temperature}

During the test the predicted local collapse of the structure was not reached, see Fig. 9. Fig. 10 compares the temperatures recorded in the compartment with the parametric curve presented in Eurocode 1, Annex A [19]. The quantity of thermal load and the dimensions of the opening on the facade wall were designed to achieve a representative fire in the office building. The maximum recorded compartment temperature near the wall (2 $250 \mathrm{~mm}$ from D2) was $1107.8^{\circ} \mathrm{C}$ after $54 \mathrm{~min}$, 


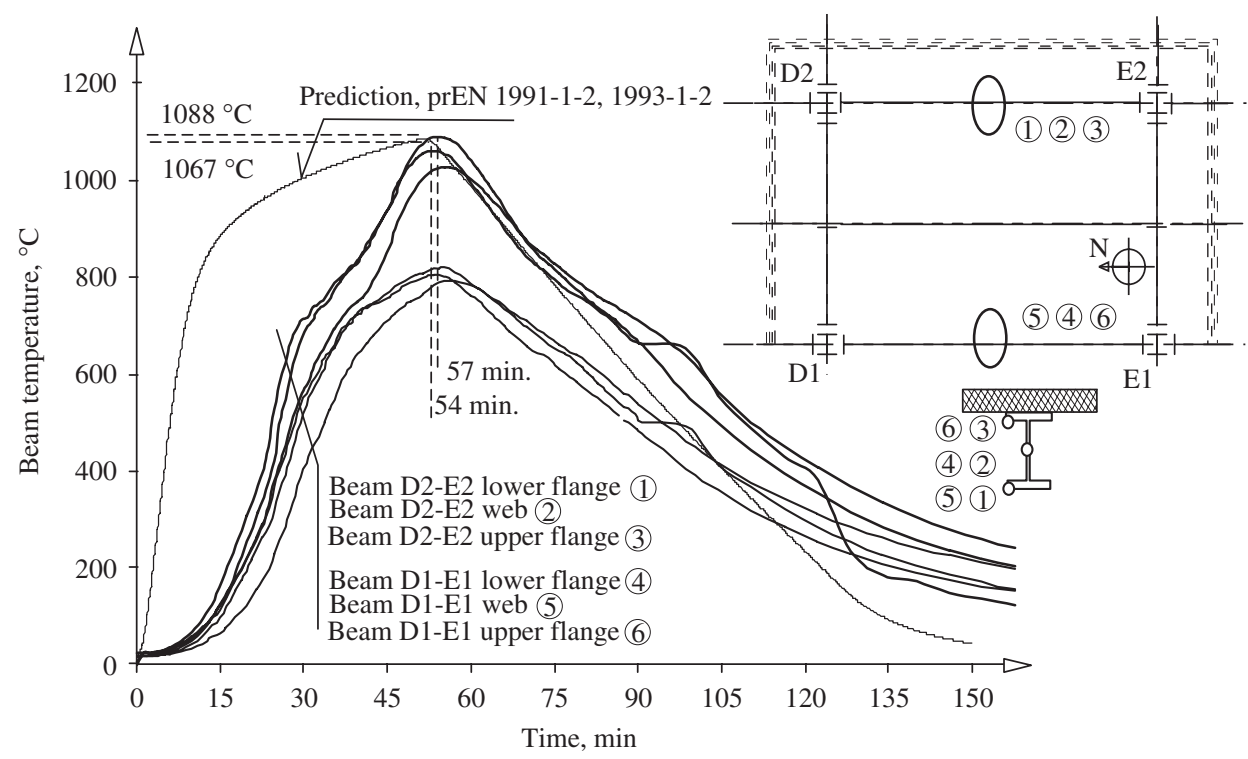

Fig. 11. Differential relative temperature variation within the beams D1-E1; D2-E2.

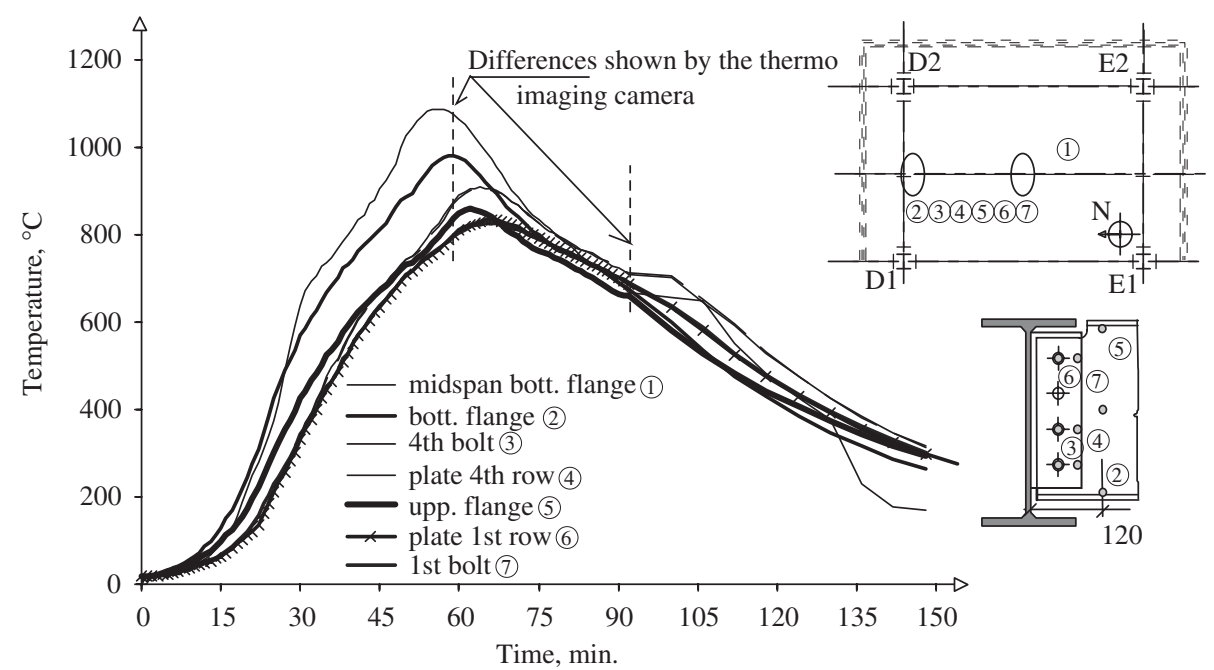

Fig. 12. Differential relative temperature variation within the beam-to-beam fin plate connection D1/2-E1/2.

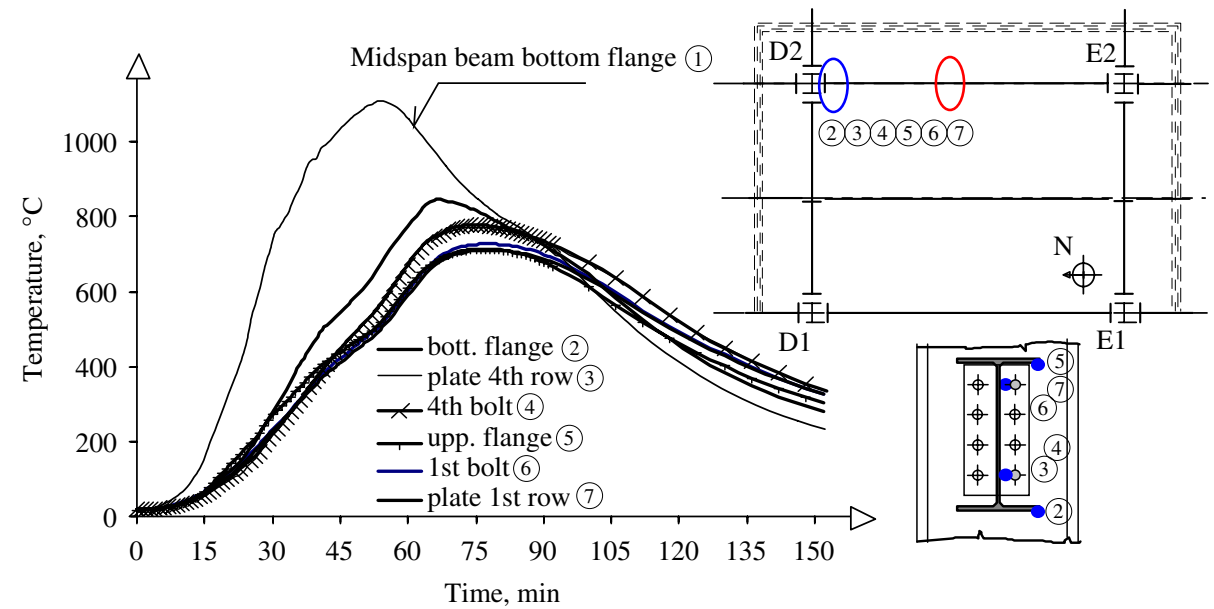

Fig. 13. Differential relative temperature variation within the beam-to-column minor axes end plate connection D2-E2. 
while the predicted temperature was $1078^{\circ} \mathrm{C}$ in $53 \mathrm{~min}$, see [16].

\subsection{Temperature evolution in the structure}

Measurements of the temperature in the mid-span beams were taken on the bottom flange, on the web and on the upper flange. A summary of the temperatures recorded in the beams is presented in Fig. 11. The maximum recorded steel temperature of $1087.5^{\circ} \mathrm{C}$ occurred after $57 \mathrm{~min}$ of fire, on the bottom flange of beam DE2 in the middle of the section. By calculation, using a step by step procedure for the heat transfer into the unprotected steel structure, see [20, (Eq. 4.24)] and with the help of the time-temperature curve measured on the compartment, a maximum steel temperature of $1067^{\circ} \mathrm{C}$ in $54 \mathrm{~min}$ was predicted.

Measurements of the temperature in the connections were taken on the beam adjacent to the connection, in the plate and in the bolts. A summary of the temperatures recorded in the connections is presented in Figs. 12-14.

In the heating phase, the joint temperature is significantly lower than the remote bottom flange, which is usually the critical element that defines the limiting temperature of the beam; in contrast, the cooling down

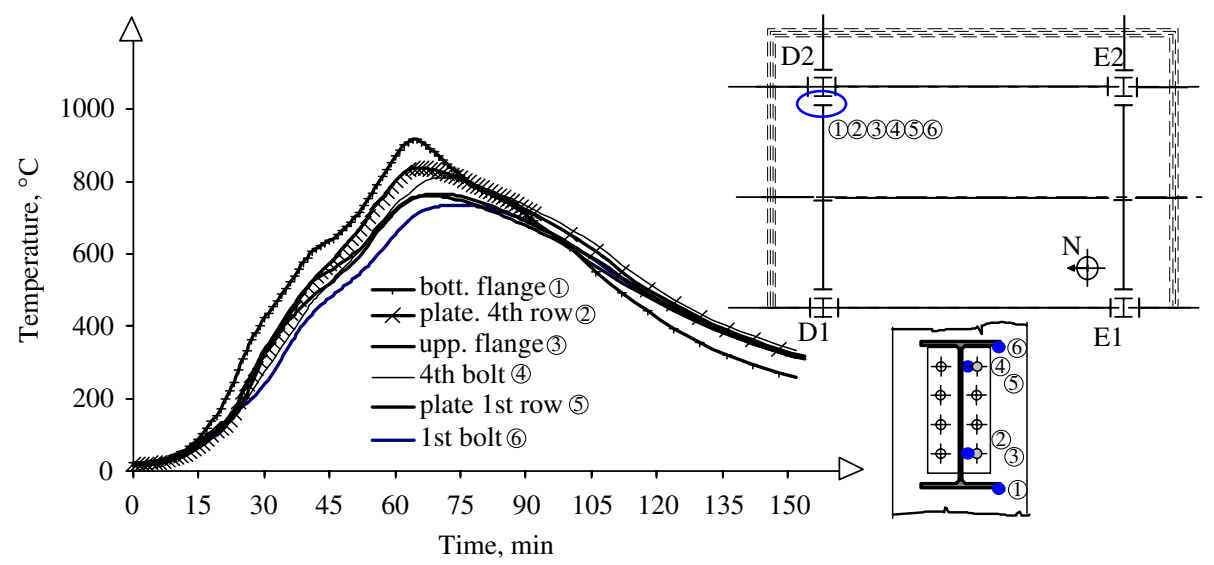

Fig. 14. Differential relative temperature variation within the beam-to-column major axes end plate connection D2-D1.

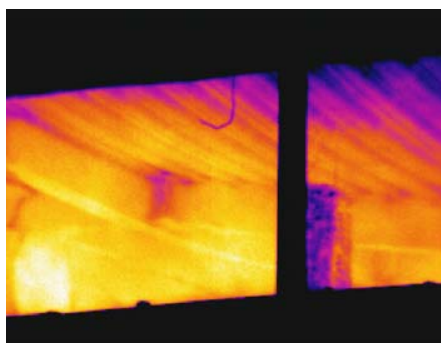

(a)

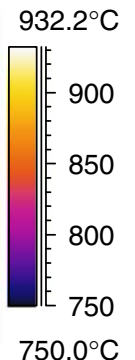

$750.0^{\circ} \mathrm{C}$

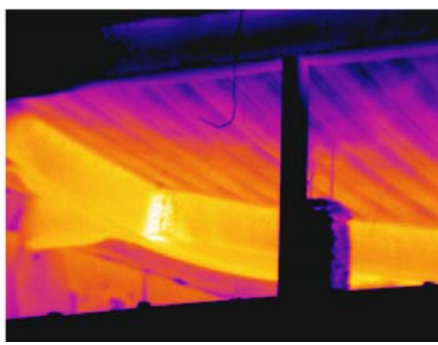

(b) $597.1^{\circ} \mathrm{C}$

550

500

450

400

$390.0^{\circ} \mathrm{C}$

Fig. 15. Fin plate connection D1-2 recorded by thermo imaging camera (a) during heating after 58 min of fire; (b) during cooling after 92 min.

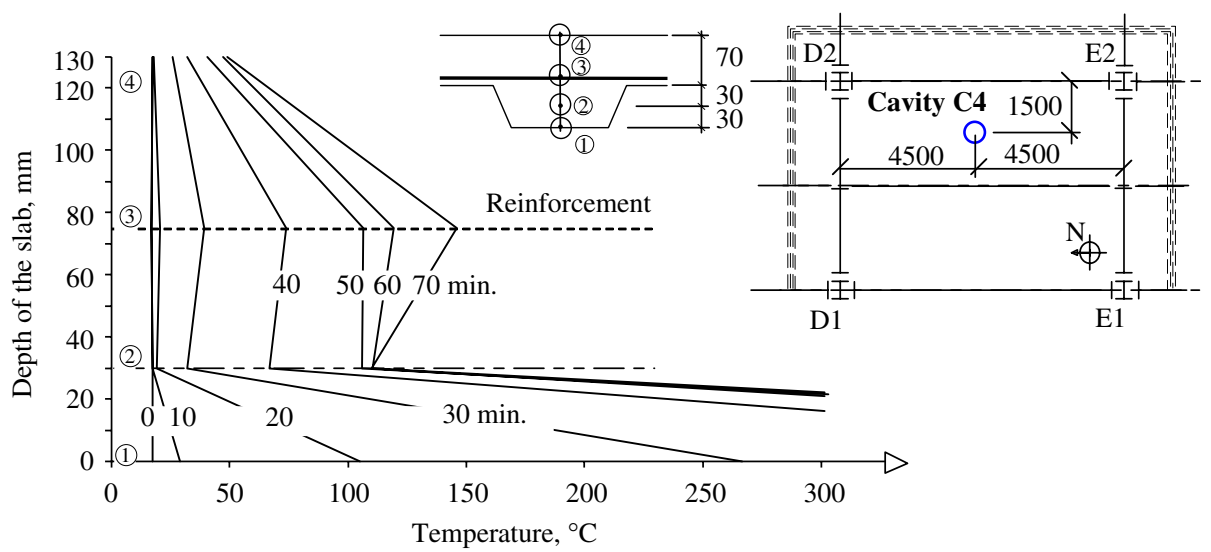

Fig. 16. Differential relative temperature variation within slab over the rib, cavity $\mathrm{C} 4$. 
in the joints was slower. Using the thermal cameras it was possible to observe this effect, see Fig. 15.

The maximum joint temperature was around $200{ }^{\circ} \mathrm{C}$ lower than the maximum temperature of the beam. The first bolt row from the top was significantly cooler than the lower bolts, because of shielding by the adjacent slab and column. The end-plate was hotter than the bolts at the same level due to the ratio of the bolt diameter to the endplate thickness $(20 \mathrm{~mm})$.

A summary of the temperatures recorded in the slab is presented in Fig. 16 for temperatures in the reinforcement over the rib.
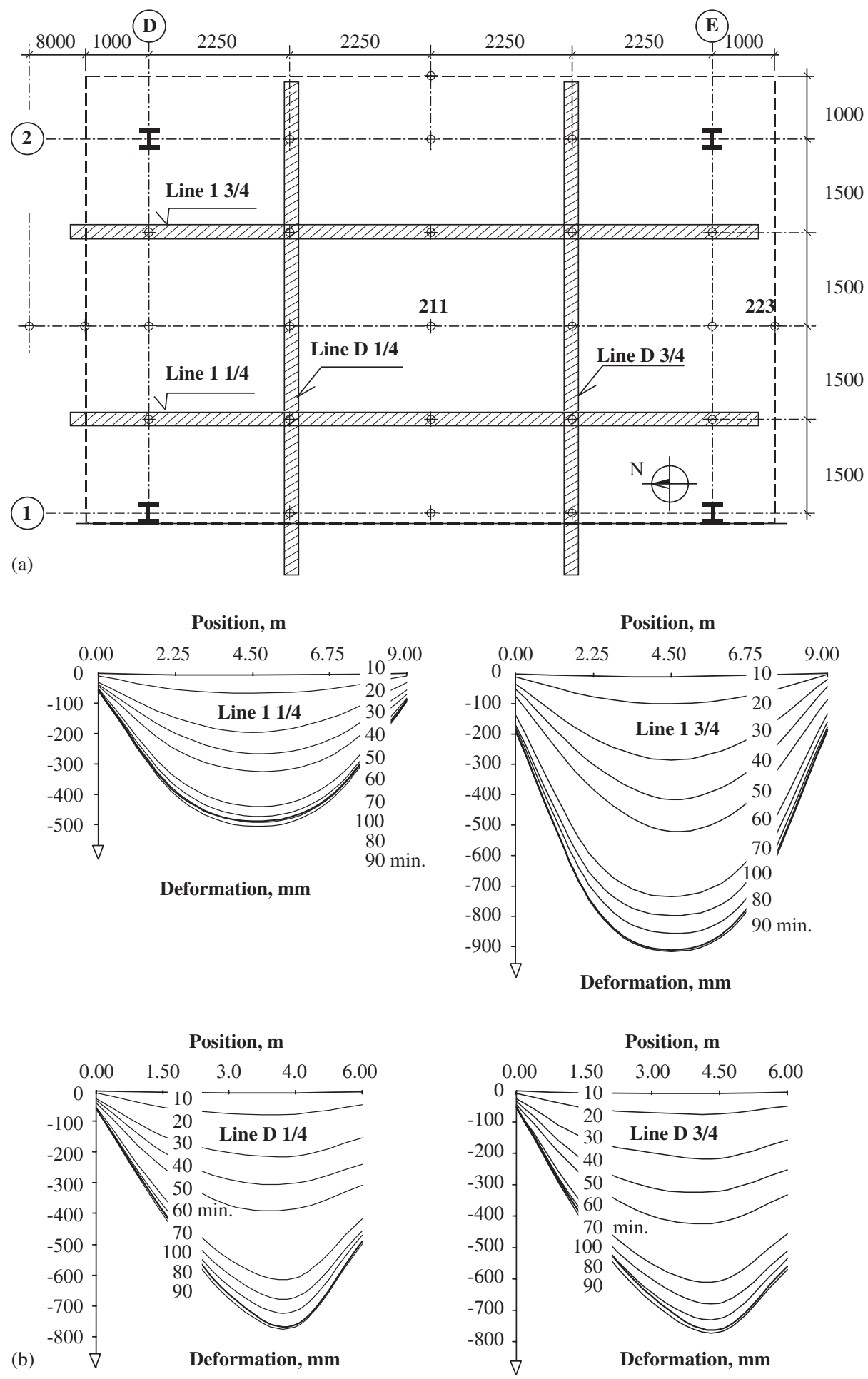

Fig. 17. Vertical deformations; (a) measured points, (b) reached values at drawn lines, ${ }^{*}$ deflection more then $900 \mathrm{~mm}$ may be affected by the limited record in transducers. 


\subsection{Behaviour of the structural members}

The maximum deflections were not recorded by the displacement transducers because its range was limited to $1000 \mathrm{~mm}$ minus the initial offset. From the video cameras on the 5th floor it is possible to recalculate a maximum vertical displacement of about $1200 \mathrm{~mm}$. Fig. 17 shows the vertical displacement recorded in beams D1-E1, D1/2-E1/2, D2-E2. Comparing the different secondary beams, it is observed that during the heating phase, the beam with a lower displacement is the beam near the window, because of lower temperatures, while the beam near the internal wall shows the biggest displacement. In the cooling phase, both these beams partially recovered.

Local buckling of the beam lower flange was one of the main failure mechanisms. It is observed in the lower beam flange and web adjacent to the joints, see Fig. 18, the concrete slab having restrained the upper flange. This local buckling occurs during the heating phase after about $23 \mathrm{~min}$ of fire (observed by thermo imaging camera), due to the restraint to thermal elongation provided by the adjacent cooler structure and the structural continuity of the test frame. The heated lower flange of the beam is unable to transmit the high normal forces generated in the lower flange of the beam to the adjacent beams/columns after closure of the gap in the lower part of the connections. The beam could be assumed to behave as 'simply supported', allowing larger mid-span deflections to develop. This phenomenon was numerically predicted by Lamont and Usmani [21].

As temperature and the associated deformations increase, shear buckling of the beam web was observed, see Fig. 19.
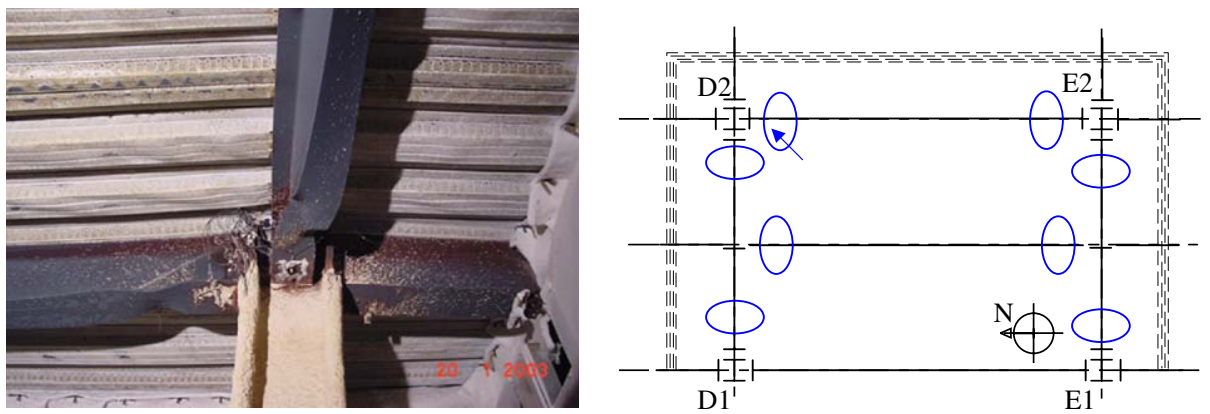

Fig. 18. Local buckling of beam lower flange.
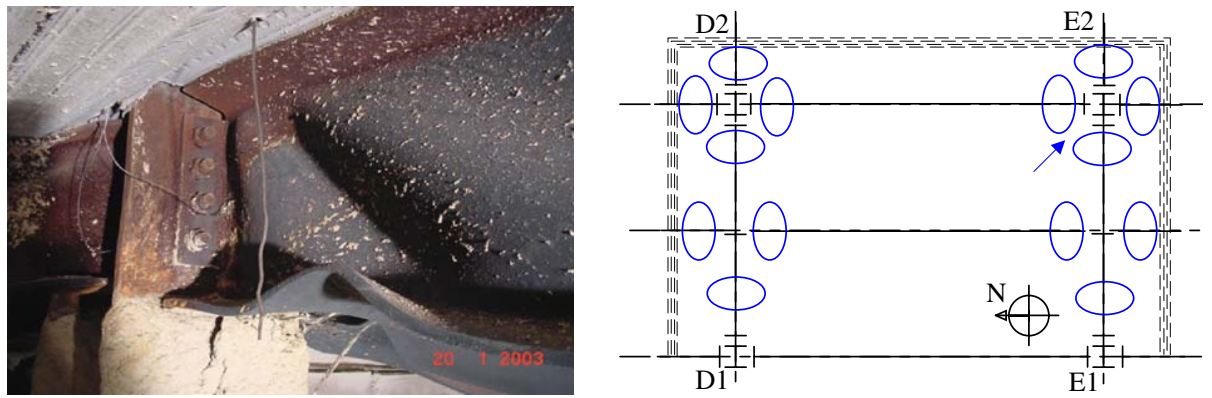

Fig. 19. Beam web in shear.
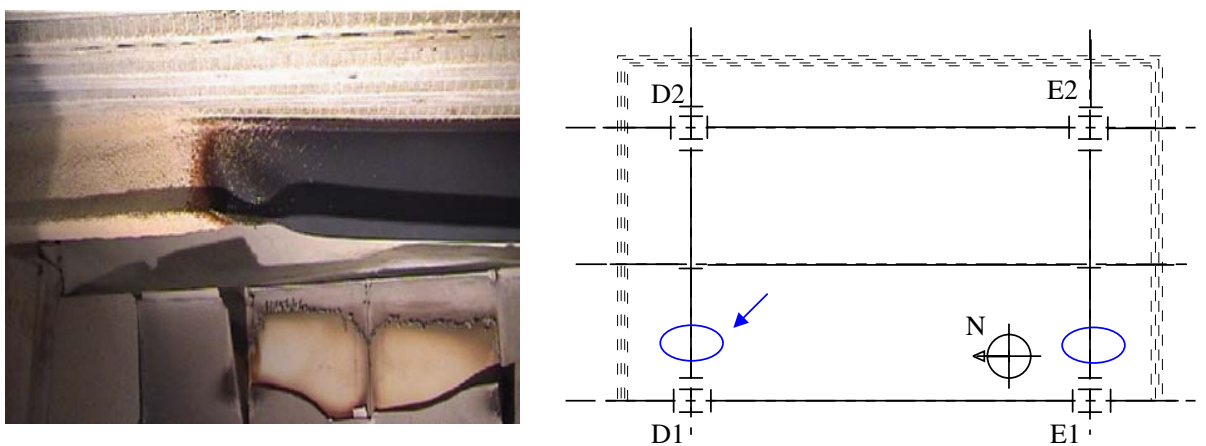

Fig. 20. Plastic hinge in the unprotected beam cross-section close to the end of the fire protection. 
The formation of a plastic hinge in the beam crosssection next to the protected zone was one of the main observed mechanisms in the main beam D1/2, see Fig. 20. This hinge is induced by distortional buckling during the first stage of the heating phase, due to the restraint to thermal elongation provided by the adjacent protected section. This behaviour is associated with the local loss of stability in the bottom flange. Subsequently, during the second stage of the heating phase, the beam rotates around this point due to the large mid-span deflection.
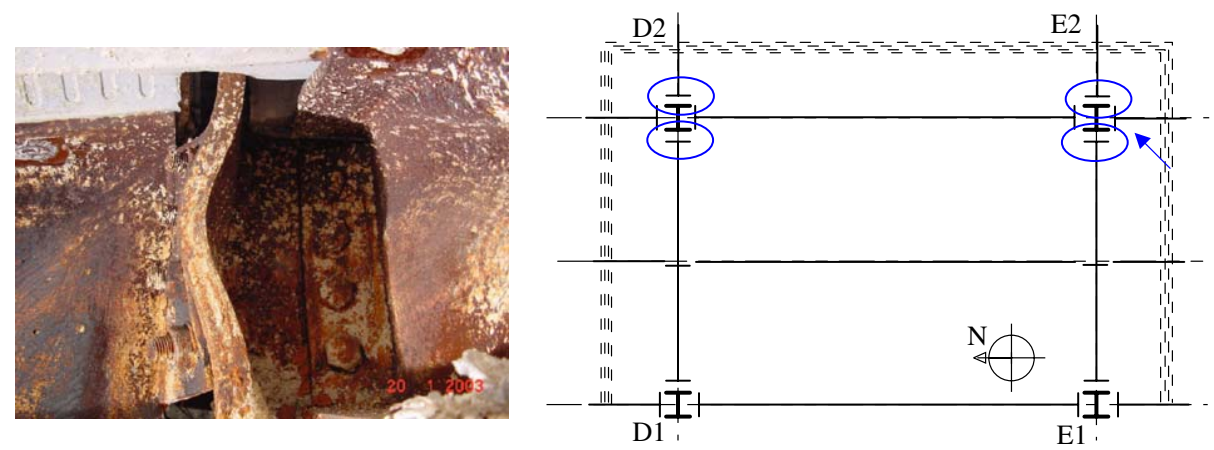

Fig. 21. Buckling of column flange in compression, column E2.
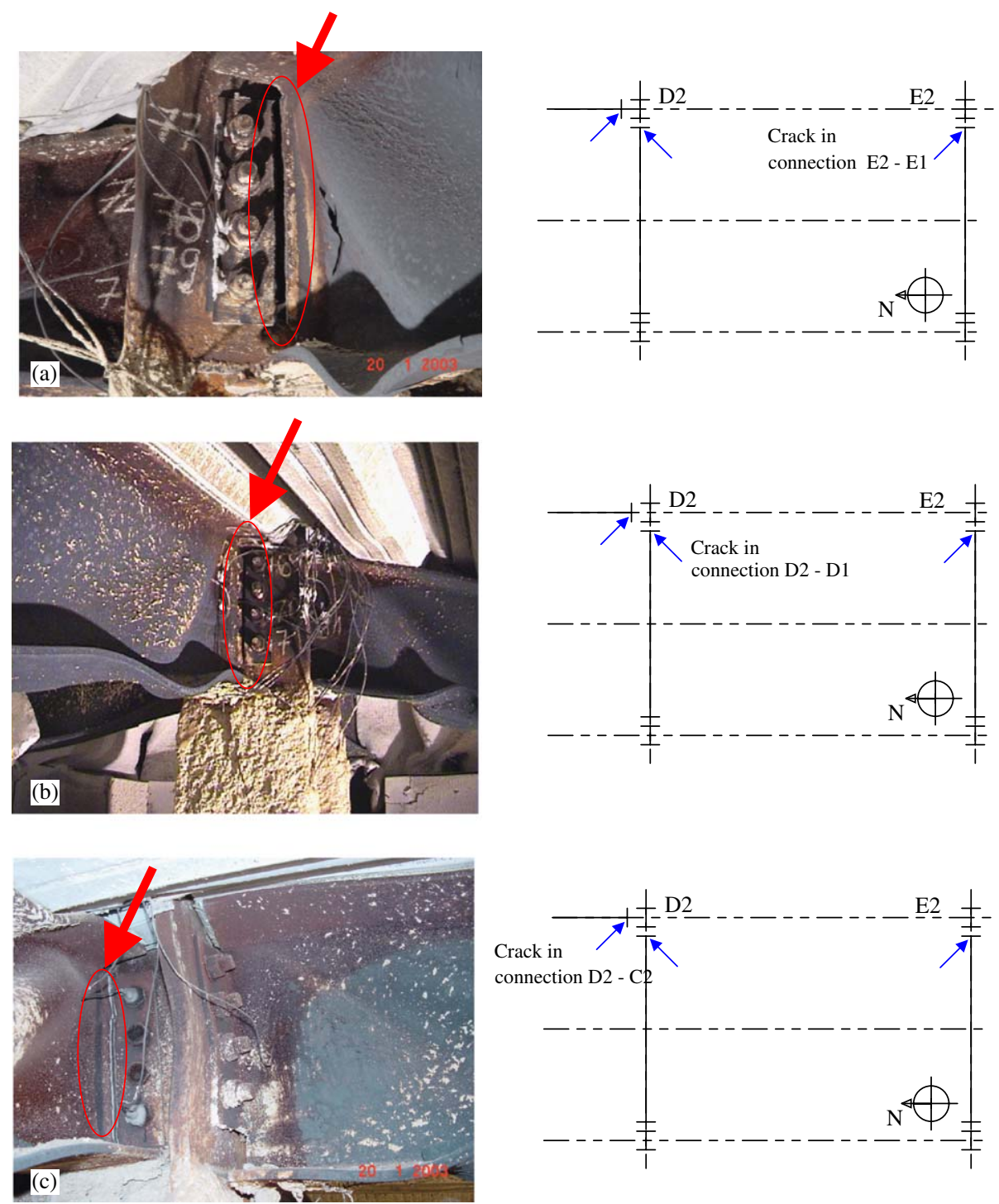

Fig. 22. Fracture of the end-plate along the welds, connections D2-D1; E2-E1, D2-C2. 

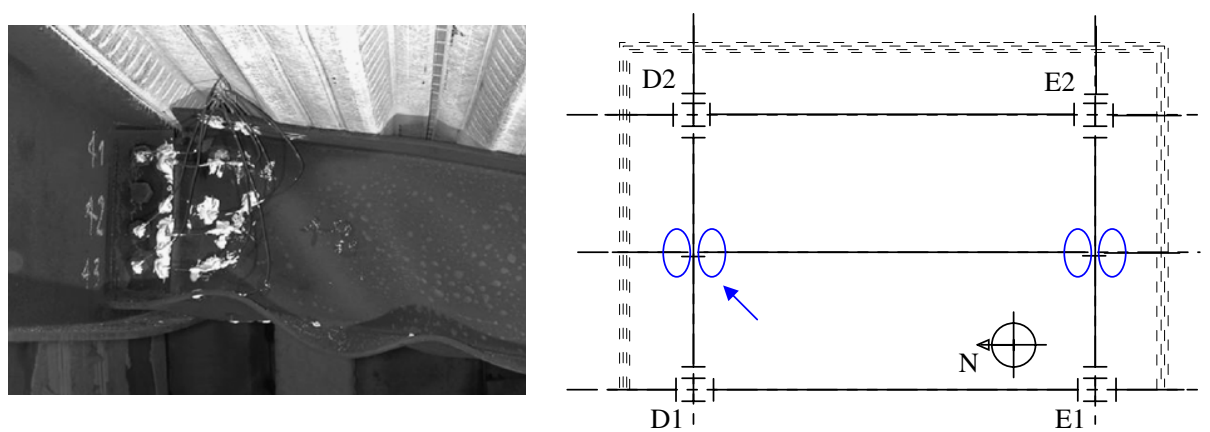

Fig. 23. Elongation of holes in the beam web in fin plate connection.

Due to the end-plate loading, bending in the column flange was observed in one of the major axis beam-tocolumn joints, see Fig. 21. This behaviour results from the small column flange thickness $(t=21.4 \mathrm{~mm})$ and the small distance between the bolts, the bolted end-plate behaving as a welded joint. This behaviour was observed in both columns flanges of the two beam-to-column joints (D2; E2).

\subsection{Behaviour of the connections}

Fracture of the end-plate along the welds was observed, caused by the horizontal tensile forces during cooling of the connected beam under large rotations associated with flexible end-plate joints, see Fig. 22. The fracture occurred along one side of the connection only, while the other side remained intact. After one side has fractured, the increased flexibility allowed larger deformations without further fracture. This behaviour was observed in both the major axis beam-to-column joints (D2-D1; E2-E1) and the minor axis beam-to-column joints (D2-C2).

The elongation of the holes in the beam web in the tension/compression part of the fin plate connection is due to the associated large rotations, see Fig. 23. The elongation of the holes occurred on the web of connected beam, while the fin-plate remained intact: the beam web thickness $(6 \mathrm{~mm})$ is smaller than the fin-plate $(10 \mathrm{~mm})$; again, the elongation of the holes of the beam web leads to increased joint flexibility, allowing larger deformations without further fracture.

\subsection{Composite slab behaviour}

Fracture in the concrete slab was observed, a large crack propagating from the face of the column flange parallel to the beam (D2-E2), see Fig. 24. This crack developed due to the tension in the concrete slab, along the weak zone in the composite beam-flange extremity. After the concrete cracked, the joint stiffness gradually decreased. Secondary cracks occurred perpendicular to, and continuous across, the connections on both sides of the slab, see Fig. 25. The maximum vertical displacement occurred along a line of mesh reinforcement overlap (without adequate attachment). This led to slippage of the mesh and the

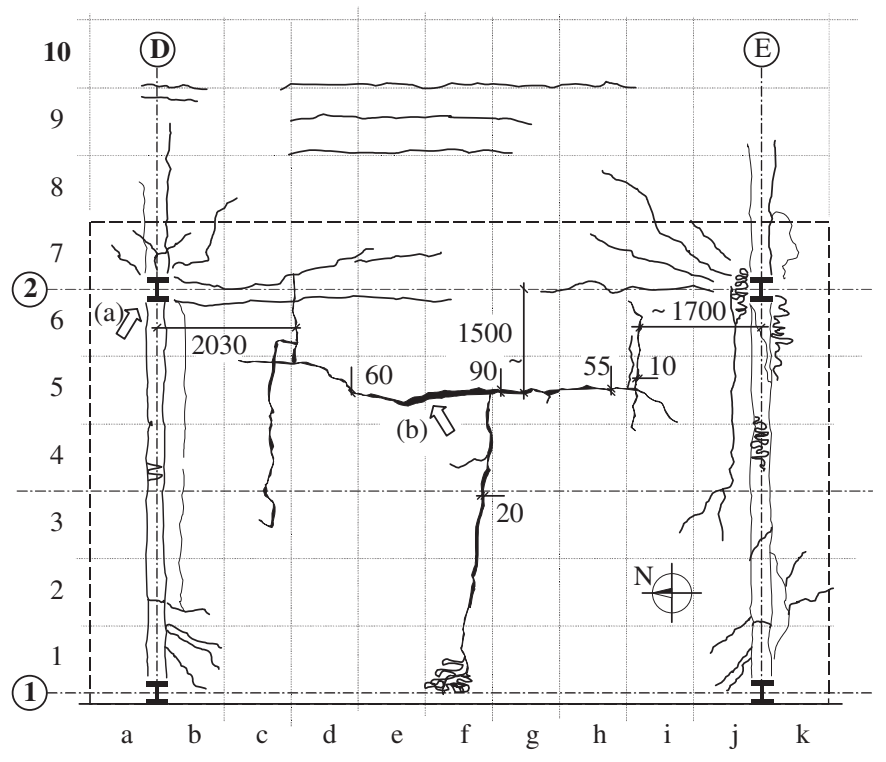

Fig. 24. Mesh of cracks in concrete slab.

corresponding behaviour of the slab was "de facto" without reinforcement.

The cameras above the fire compartment recorded loss of the integrity limit state of the concrete slab after $54 \mathrm{~min}$. The opening of the composite slab took place around column E2 by a punching mechanism due to the tension in the concrete slab in the edge compartment. Furthermore, many tiny cracks were observed in different areas of the concrete slab.

\section{Conclusions}

Collapse of structure was not reached, thus allowing to demonstrate that the structure has adequate fire safety for the fire load of $40 \mathrm{~kg} / \mathrm{m}^{2}$ of wood cribs, which represents a design fire load in a typical office building, coupled with a mechanical load in excess of typical serviceability conditions. The test results fully supported the concept of unprotected beams and connections with protected columns as a viable system for composite floors [18].

The local buckling of the lower flanges of beams was observed after $23 \mathrm{~min}$ of fire. Fracture of the end plates 


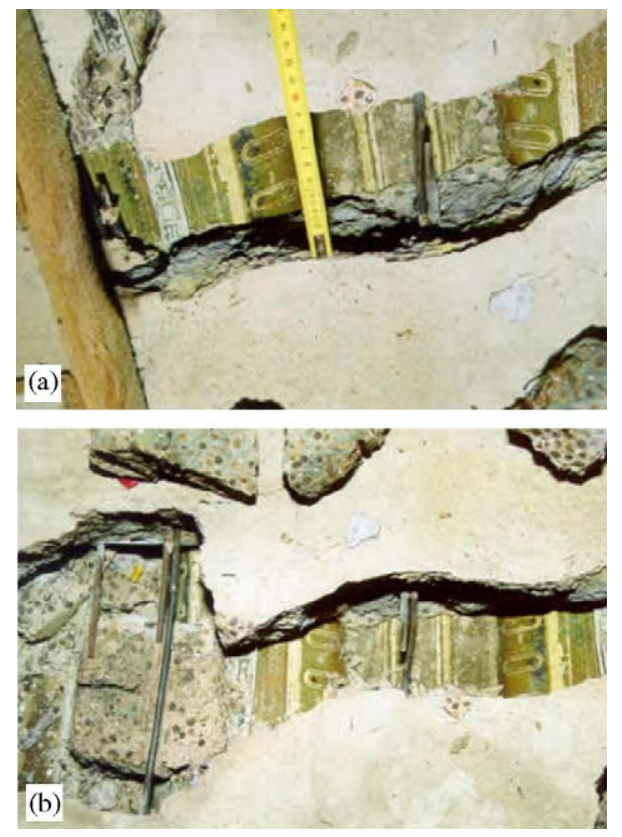

Fig. 25. Reinforcement mesh (a) slippage and cracking near to the column D2, (b) largest crack/opening in the mid-span.

occurred under cooling in the heat affected zones of welds without losing the shear capacity of the connections. The fin plate connections behaved in a ductile fashion due to elongation of holes in bearing.

This test shows the conservatism of the Eurocode fire design $[19,20]$. The calculated values show good and conservative predictions of the temperature in the fire compartment, the transfer of heat into the structure and connections and the prediction of structural behaviour.

The detailed behaviour of the composite slab, connections and columns is currently being investigated to refine the analytical and numerical prediction models, preliminary published results being available in $[22,23]$. Further experimental tests on subassemblies using the boundary conditions measured on the Cardington frame test are currently being prepared to further explore the behaviour of connections, columns and beams.

\section{Acknowledgement}

The project has been supported by the grant of European Community FP5 HPRI-CV 5535 and COST C12. Paper was prepared as a part of project 103/04/2100 of the Czech Grant Agency. Financial support from the Portuguese Ministry of Science and Higher Education (Ministério da Ciência e Ensino Superior) under contract Grant POCI/ECM/55783/2004 is also gratefully acknowledged.

\section{References}

[1] Wang YC. Steel and composite structures. Behaviour and design for fire safety. UK: Spon Press; 2002.
[2] Petersson O, Magnusson SE, Thor J. Fire engineering design of steel structures, Publication No. 50, Swedish Institute of Steel Construction, Stockholm, 1976.

[3] Witteveen J, Twilt L, Bijlaard FS. The stability of braced and unbraced frames at elevated temperatures. International symposium of stability of steel structures, Liège, 1977.

[4] Kruppa J. Some results on the fire behaviour of external steel columns, Fire Saf J. 1981/2; 4:p. 247-57.

[5] Genes DC. Predicted fire endurance of steel structures. American Society of Civil Engineering Conference, Las Vegas 1982. New York, ASCE, 1982.

[6] Latham DJ, Kirby BR, Thomson G. The temperature attained by unprotected structural steelwork in experimental natural fires. Fire Saf J. 1987(12):139-72.

[7] Rubert A, Schaumann P. Structural steel and plane frame assemblies under fire action. Fire Saf J 1986(10):173-84.

[8] Anon T. Fire behaviour of steel and composite construction. Verlag, TUV, Rheinland, 1986.

[9] Cooke GME, Latham DJ. The inherent fire resistance of a loaded steel framework. Steel Const Today 1987(1):49-58.

[10] Thomas IR, et al. The effect of fire in the building at 140 William Street Office Building. BHP Research-Melbourne Laboratories report, 1992.

[11] Bravery PNR. Cardington Large Building Test Facility, Construction details for the first building. Building Research Establishment, Internal paper, Watford 1993. p. 158.

[12] Moore DB. Steel fire tests on a building framed. Building Research Establishment, Paper no. PD220/95, Watford 1995. p. 13.

[13] Lennon T. Cardington fire tests: survey of damage to the eight storey building. Building Research Establishment, Paper no. 127/97, Watford 1997. p. 56.

[14] Moore DB, Lennon T. Fire engineering design of steel structures. Prog Struct Eng Mater 1997;1(1):1997.

[15] Bailey CG, Lennon T, Moore DB. The behaviour of full-scale steelframed building subject to compartment fires. Struct Eng 1999;77(8):15-21.

[16] Wald F, Santiago A, Chladná M, Lennon T, Burgess I, Beneš M. Tensile membrane action and robustness of structural steel joints under natural fire. Internal report, Part 1-Project of measurements; Part 2-Prediction; Part 3 - measured data; Part 4 - Behaviour, BRE, Watford, 2002-2003.

[17] Beneš M, Wald F, Sokol Z, Pascu HE. Numerical study to structural integrity of multi-story buildings under fire. In: Lamas A, Simões da Silva L, editors. Proceedings of the third European conference on steel structures-Eurosteel 2002. Coimbra, Portugal: cmm Press; 2002. p. 1401-11.

[18] ECSC 2002: Design recommendations for composite steel framed buildings in fire. Proj. 7210 PA, PB, PC, PD112, December 2002. p. 108.

[19] CEN, Eurocode 1, Draft prEN-1991-1-2: 200x, Part 1.2: General actions - actions on structures exposed to fire, Eurocode 1: actions on structures, Final Draft, 2002, CEN, European Committee for Standardization, Brussels, 2002.

[20] CEN, Eurocode 3, prEN-1993-1-2: 2003, Part 1.2: Structural Fire Design, Eurocode 3: Design of steel structures, Stage $49 \mathrm{draft}$, April 2003, CEN, European Committee for Standardization, Brussels, 2003.

[21] Lamont S, Usmani AS. Possible 'panel-instability' in composite deck floor systems under fire. J Const Steel Res 2003;59:1397-433.

[22] Santiago A, Simões da Silva L, Vila Real P, Franssen J-M. Effect of cooling on the behaviour of a steel beam under fire loading including the end joint response. In: Topping BHV, editor. Proceedings of the ninth international conference on civil and structural engineering computing. Stirling, United Kingdom: Civil-Comp Press; 2003 paper 65.

[23] Sokol Z, Wald F, Pultar M, Beneš M. Numerical simulation of Cardington fire test on structural integrity. In: Kočandrlová M, Kelar $\mathrm{V}$, editors, Mathematical and computer modelling in science and engineering,CTU, 27-30.1.03, 2003. p. 339-343. 